CÁtia LOUREnÇO ${ }^{1}$

NunO OLIVERA ${ }^{2}$

FILOMENA RAMOS ${ }^{2}$

ISABEL FerReira ${ }^{2}$

MÁrio OliverRA ${ }^{2}$

\title{
Aggressive angiomyxoma of the vagina: a case report
}

\author{
Angiomiosarcoma agressivo da vagina: relato de caso
}

Case Report

Vulvar neoplasms/diagnosis Vaginal neplasms/diagnosis

Case reports

Palavras-chave

Mixoma/etiologia Mixoma/diagnóstico

Mixoma/terapia

Pelve

Neoplasias vulvares/diagnóstico Neoplasias vaginais/diagnóstico

Relatos de casos

Correspondence

Cátia Sofia Ferreira Pinto Lourenco

Rua do Casqueira, 307

Código postal: 4505-472

Lobão, Portugal

Received

08/05/2013
Abstract

Aggressive angiomyxoma is a rare, slow-growing soft tissue tumor that usually arises in the pelvis and perineal regions of women in reproductive age, with a marked tendency to local recurrence. Because of its rarity, it is often initially misdiagnosed. Surgical resection is the main treatment modality of aggressive angiomyxoma. We describe a case of a vaginal aggressive angiomyxoma in a 47-year-old woman in which the diagnosis was only made after histological examination. The etiology, presentation, diagnosis and management of this rare tumor are outlined. Angiomyxoma of vulva and vagina refers to a rare disease. Pre-operative diagnosis is difficult due to rarity and absence of diagnostic features, but it should be considered in every mass in genital, perianal and pelvic region in a woman in the reproductive age. Thus, these cases should have complete radiological workup before excision, as pre-diagnosis can change the treatment modality and patient prognosis'.

\section{Resumo}

angiomixoma agressivo é tumor raro de tecidos moles, de lento crescimento e que geralmente ocorre na pelve e nas regiões perineais de mulheres em idade reprodutiva, com forte tendência à recorrência local. Devido à sua raridade, ele é frequentemente mal diagnosticado. A exerese cirúrgica é a modalidade principal para o tratamento do angiomixoma agressivo. Descrevemos aqui um caso de angiomixoma vaginal agressivo em mulher de 47 anos de idade, que foi diagnosticado apenas após exame histológico. Descrevemos também a etiologia e apresentação, bem como o diagnóstico e tratamento desse raro tumor. $\bigcirc$ angiomixoma da vulva e vagina constitui doença rara. Devido à raridade desse tumor e à ausência de elementos diagnósticos, o diagnóstico pré-operatório é difícil, mas deveria ser considerado na presença de qualquer massa na região genital, perianal e pélvica de mulheres em idade reprodutiva. Portanto, esses casos deveriam ser submetidos a propedêutica radiológica completa antes da exerese, uma vez que um pré-diagnóstico pode modificar a modalidade de tratamento e o prognóstico do paciente.
'Centro Hospitalar de Vila Nova de Gaia/Espinho - Vila Nova de Gaia, Portugal.

${ }^{2}$ Centro Hospitalar do Baixo Vouga - Aveiro, Portugal.

Conflict of interests: none. 


\section{Introduction}

Aggressive angiomyxoma (AA) is a rare tumor of mesenchymal origin first described in 1983 by Steeper and Rosai ${ }^{1}$ and, since then, less than 150 cases have been reported in the literature ${ }^{2}$. About $95 \%$ of the patients are women (female-to-male ratio is 6.6/1), usually of reproductive age, with a peak incidence between the third and fourth decades of life $e^{3-7}$. AA is a rare locally aggressive myxoid mesenchymal tumor, usually arising in the deep soft tissues of the vulvovaginal region, perineum and pelvis of young adult females. In men, the tumor involves analogous sites including the scrotum and inguinal area and usually appears at an older age $e^{8-10}$. It is a slow growing tumor, but problematic due to frequent local recurrences (30-72\%), sometimes years later ${ }^{1,9,11}$. However, the recurrence rate in patients with narrow surgical margins is not higher than the one in patients with wide surgical margins ${ }^{12}$. However, metastases are very uncommon ${ }^{3}$ and misdiagnosis is a very frequent problem ${ }^{7}$. Diagnosis, more often than not, is made at histological examination following surgical resection ${ }^{8}$.

We describe a case of vaginal mass in a 47-year-old woman in which the diagnosis of AA was made after histological examination, and try to discuss management options and subsequent follow-up.

\section{Case report}

A 47-year-old woman, G1P1, with prior history of a right temporal meningioma, obesity and gallstones, complained of a painless swelling of the vagina that she had noticed a few months before. The patient presented a history of excision of a vaginal mass five years ago, but had no histopathology report or medical documents. Clinical examination showed a $9 \times 7 \mathrm{~cm}$ non-tender cyst with smooth surface in the left posterolateral wall of the vagina looking like a

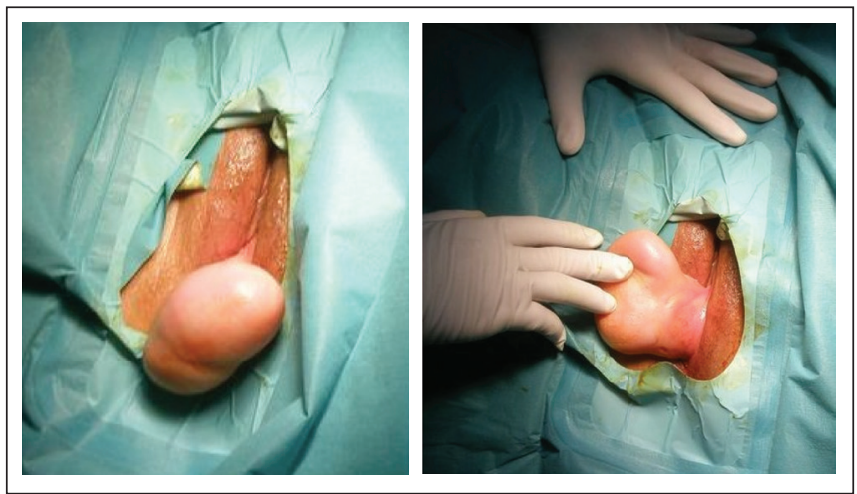

Figure 1. Clinical presentation: a $9 \times 7 \mathrm{~cm}$ non-tender cyst with smooth surface in the left posterolateral wall of the vagina looking like a vaginal cyst was evident. vaginal cyst. The patient underwent surgery under anesthesia for removal of the vaginal mass (Figure 1). The pediculated lesion was removed but its superior border continued in direction of the obturator fossa, so the removal of the tumor was incomplete.

The tumor $(8 \times 7 \times 5 \mathrm{~cm})$ weighed $103 \mathrm{~g}$. Histopathological examination revealed a hypocellular mesenchymal lesion characterized by sparse scattered stellate cells without atipia or mitosis diffusely spread in a myxoid stroma. The lesion showed numerous vessels, with thick walls. Immunohistochemically, the stromal cells showed expression of smooth-muscle actin, desmin and vimentin (Figure 2). Based on the clinical presentation and the morphological and immunohistochemical findings, the diagnosis of aggressive angiomyxoma (AA) was made. The profound margin was involved by the tumor, as expected.

A magnetic resonance imaging (MRI) was performed to better characterize the extent of the tumor. This MRI revealed a nodular structure between the left vaginal wall and the internal obturator muscle, heterogeneous, with $6 \times 5 \mathrm{~cm}$ and ill-defined margins that deviate the vagina for the right and continues to the skin of the buttock; the lesion has increased signal intensity on T2-weighted sequence (Figure 3).

The patient underwent surgery again under anesthesia to remove the residual tumor. The lesion was excised by an approach in the left buttock (Figure 4). Macroscopically, the tumor was $39 \mathrm{~cm}$ long, weighed $80 \mathrm{~g}$ and, on cut section, it had a grey-bluish appearance (Figure 5). Histopathological examination revealed

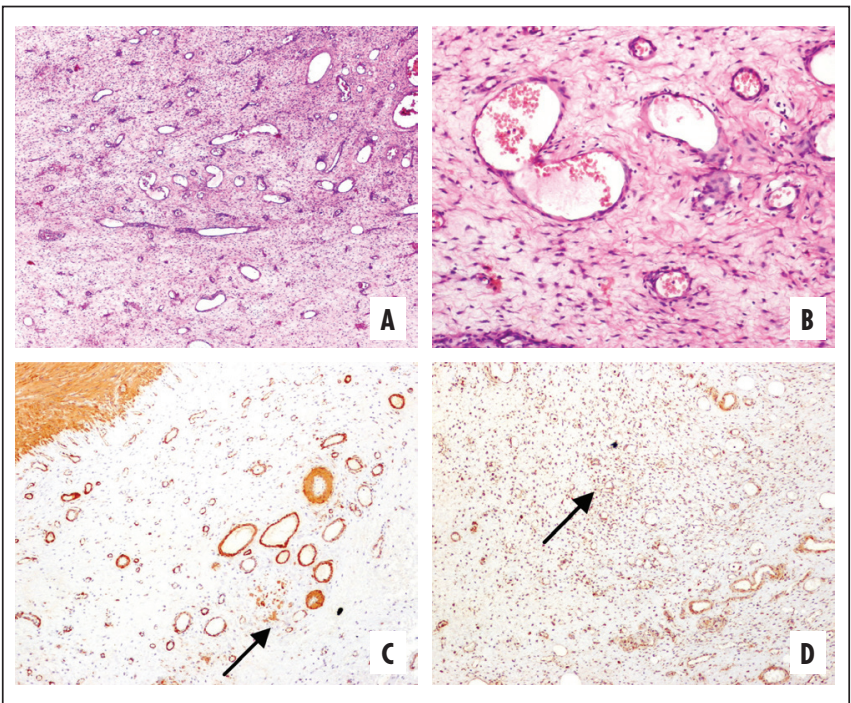

Figure 2. Microscopic findings of the tumor. (A) histologic examination showing numerous blood vessels in a hypocellular myxoid stroma with satellite or spindle cells (hematoxylin and eosin stain, $\times 40$ ); (B) the tumor shows medium-sized vessels with perivascular hyalinization and thickened walls (hematoxylin and eosin stain, $\times 200$ ); (C) a few tumor cells reveal positive reactivity for smooth muscle actin (SMA) immunohistochemical staining (arrows, SMA, $\times 400$ ); (D) tumor cells reveal positive reactivity for vimentin (arrows, vimentin, $\times 400$ ). 
a tumor with similar characteristics. Study of hormonal receptors revealed estrogen positivity in $20 \%$ of the cells and progesterone positivity in $40 \%$ of the cells.
The postoperative follow-up was uneventful. In the appointment two months after surgery, there were no signs of recurrence.
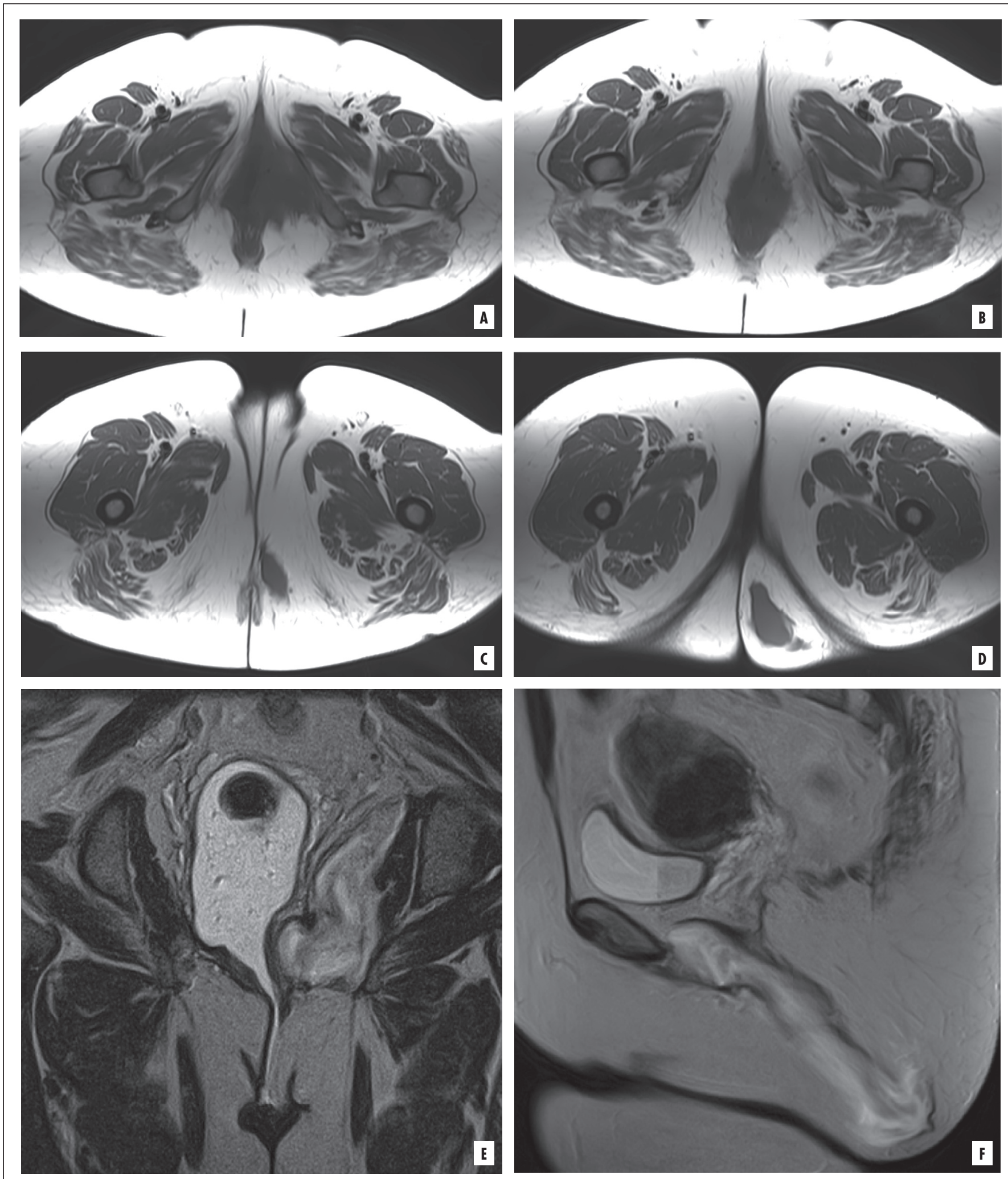

Figure 3. Magnetic ressonance imaging (MRI) of the tumor. MRI appearances of the tumor demonstrate hypointensity on T1-weighted images (A-D) and hyperintensity on T2-weighted images (E-F). An irregular mass between the left vaginal wall and the left obturator internus muscle measuring $6 \times 5 \mathrm{~cm}$, displacing the vagina to the right and extending to the skin surface of the left buttock, is evident. 


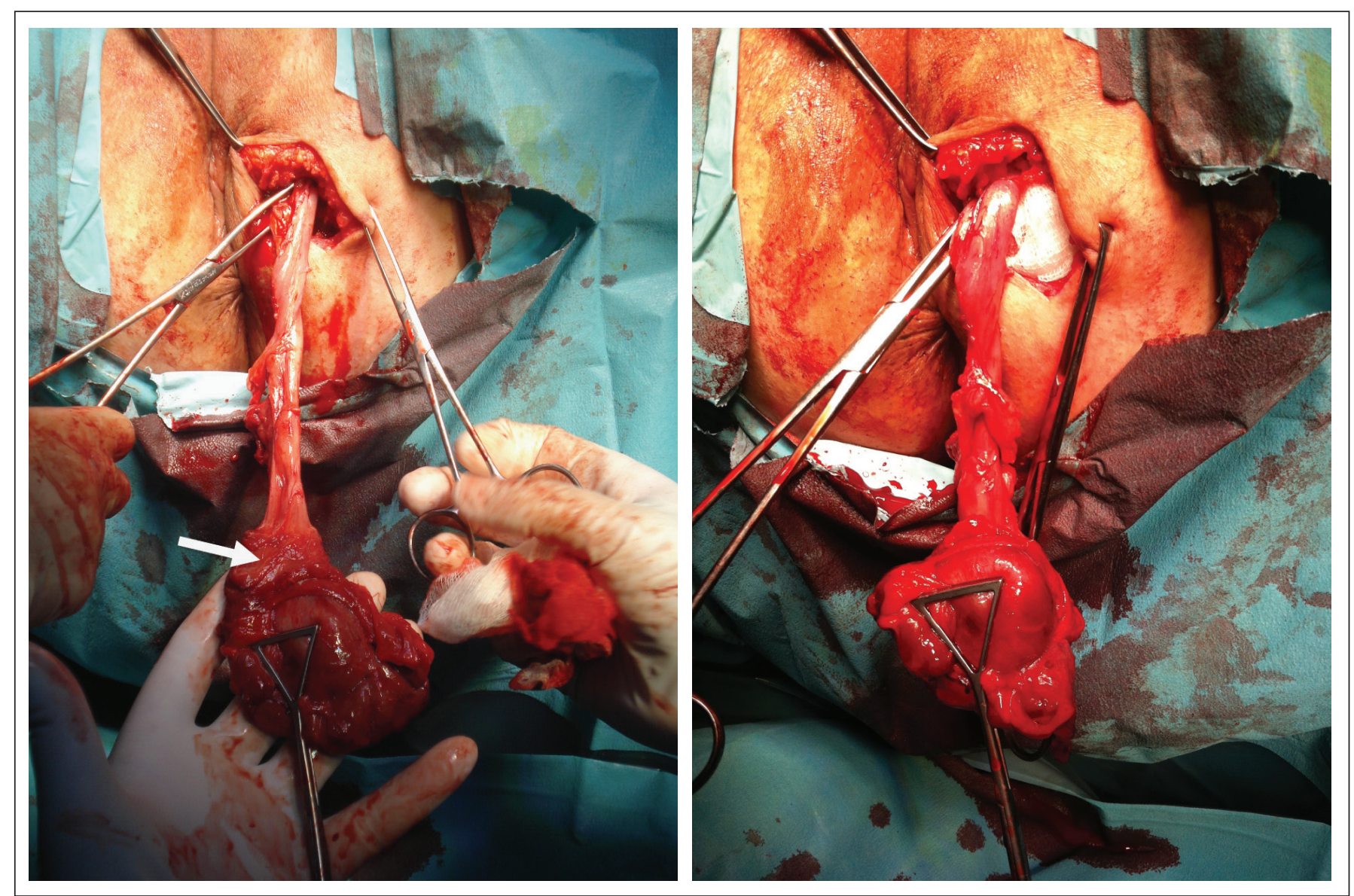

Figure 4. The tumor (arrow) was removed by an approach by the left buttock.

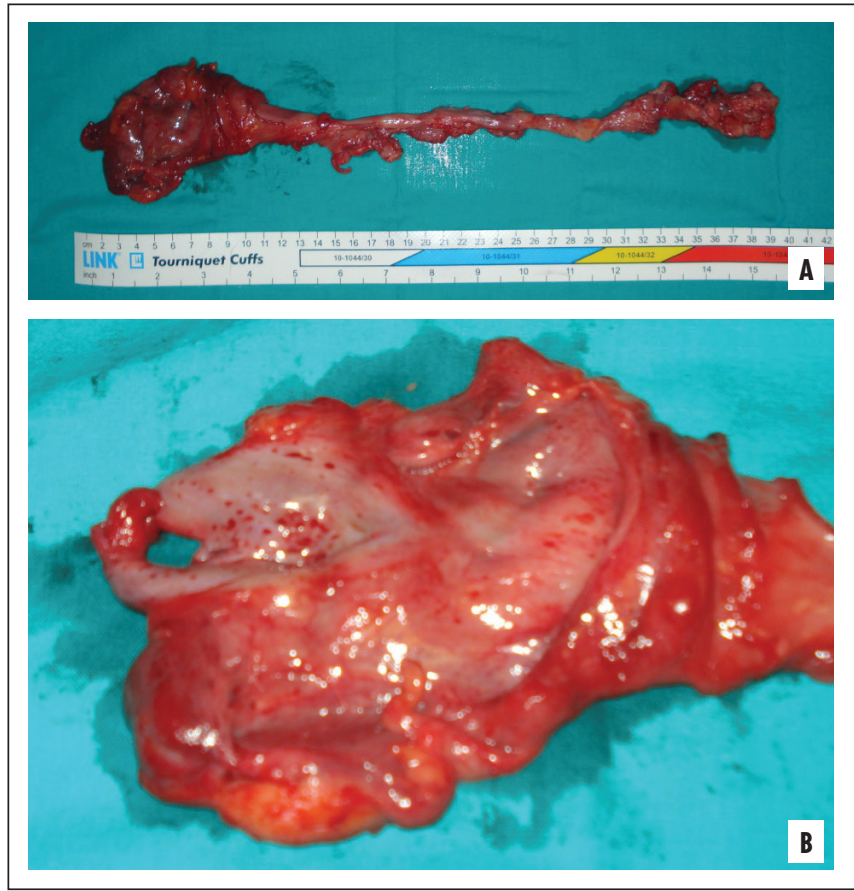

Figure 5. Tumor on gross examination $(A)$ that was $39 \mathrm{~cm}$ long and weighed $80 \mathrm{~g}$. Tumor on cut-section (B) with a grey-bluish appearance of homogeneous, gelatinous consistency.
However, six months after the initial surgery, a recurrence was evident again. At the level of the buttocks, there was nothing unusual. At the gynecological examination with a speculum, a $3 \mathrm{~cm}$ mass was evident in the left vaginal wall. The patient initiated leuprorrelin $3.76 \mathrm{mg} / \mathrm{month}$. Two months after, there was no evidence of the vaginal mass described before at clinical examination. Another pelvic MRI was performed to seek for residual tumor and it revealed an ill-defined area, with 4,3x4,5 cm, between the left vaginal wall and the internal obturator muscle, that deviates the vagina to the right and continues to the skin of the buttock; the lesion has increased signal intensity on T2-weighted sequence and decreased signal intensity on T1-weighted sequence.

It was decided to do a total abdominal hysterectomy with bilateral salpingoophorectomy and excision of the recurrence by an approach by the left buttock. The tumor weighed $13 \mathrm{~g}$ and the histopathological examination revealed the same tumoral characteristics as shown before (estrogen positivity, progesterone positivity and immunohistochemical analyses specific for this type of tumor - positivity for desmin, smooth-muscle actin and vimentin). There is no evidence of recurrence during one year follow-up. 


\section{Discussion}

Aggressive angiomyxoma of the genital region is a rare condition that has been reported to exhibit a peak incidence in young women in the third and fourth decades of life $e^{3,11}$.

Patients usually present with complaints of a noticeable mass and rarely have pain ${ }^{4}$. The size of AAs can fluctuate widely, but most of them are $>10 \mathrm{~cm}^{5,13}$. The largest AA was described in 1998 by Chen et al. ${ }^{14}$, who published a case report concerning a 38-year-old woman with a mass of $57 \times 47 \times 23 \mathrm{~cm}$ that had developed slowly over about 8 years, but particularly during pregnancy. There is no correlation between the disease and the ethnic origins, but the majority of patients are white. The tumor preferentially involves the pelvis, often located in the vagina, vulva, perineum or buttocks ${ }^{4}$. The tumor characteristically grows slowly and insidiously. It usually takes 2 months to 17 years for the patients to go to the hospital with a painless mass after the initial discovery. It may grow and occupy the whole pelvic region and invade paravaginal and pararectal spaces displacing pelvic structures ${ }^{5,15}$.

The pathogenesis of AA is poorly understood. Recently, a translocation at chromosome 12 with a consequent aberrant expression of the high mobility group protein isoform I-C (HMGI-C) protein involved in DNA transcription has been demonstrated. On one hand, the lack of consistent HMGI-C expression in the vascular component and, on the other hand, very high frequency of HMGI-C expression in the spindled stromal cells might suggest that this is the true neoplastic component and that the admixture of blood vessels may be a secondary phenomenon. Localization of HMGI-C to neoplastic stromal cells of AA by immunohistochemistry might be applied as a diagnostic tool in assessing margins status, which might be extremely difficult to assess on morphologic grounds alone $e^{3,5,8}$.

On gross examination, these tumors are characteristically soft, bulky masses. The external surface is smooth and usually appears not to be encapsulated. Some have finger-like projections that extend into neighboring tissues. A bluish grey tumor of homogeneous, gelatinous consistency with focal areas of congestion and hemorrhage is seen on cut section. AAs generally displace rather than invade adjacent viscera, and they are rarely destructive. Although invasions are rare, AAs can invade the bladder, bowel and pelvic bone $e^{3,8,10,11,15}$.

Histologically, the tumor consists of a rather hypocellular population of small, somewhat stellate and spindle-shaped neoplastic cells with thin cytoplasmic processes ${ }^{3,5,10,15}$. The cells are scattered in a loose myxoid matrix composed of delicate wavy collagen fibrils and hyaluronic acid, which gives the tumor a pale-pink color by eosin staining ${ }^{8,10,15}$. There is also an accompanying prominent vascular component, ranging from tiny capillary-like vessels to larger and thick-walled vessels with a distinct smooth muscle cell but with no evidence of anastomosis or arborization ${ }^{3,10,13-16}$.

The histogenesis of aggressive angiomyxoma has been controversial. It has been suggested a neural origin, but the imunohistochemistry for S-100 protein is negative and ultrastructural examination only rarely shows images of Schwann cells. The presence of CD31, CD34, CD44 and factor VIII and the absence of prominent basement membrane and bodies of Weibel-Palade go against an origin in endothelial cells, as proposed in the original description. It is likely that aggressive angiomyxoma arises from specialized stromal cells of the lower genital tract. Immunohistochemically, the tumor cells are positive for vimentin and weakly positive for desmin but not for myosin. These findings suggest a fibroblastic origin and differentiation of this tumor ${ }^{9,10,15-19}$. AA usually expresses estrogen (ER) and progesterone receptors (PR). However, dermal fibroblasts in normal vulvar skin and stromal cells in a variety of vulvar lesions can also be positive. ER or PR immunoreactivity cannot be used to distinguish AA and its histological mimics ${ }^{10,15}$.

The differential diagnosis with other soft tissue tumors of the female genital tract is not always clear. Among the most common are: cyst of the bartholin gland, leiomyomas, vulvar lipomas, angiomyofibroblastoma, malignant fibrohistiocytoma, myxolipoma, myxoid neurofibroma, myxoid leiomyoma, myxofibrosarcoma, leiomyosarcoma, lymfangioma, neurofibroma malignant mesenchymoma, sclerosing hemangioma and botryoid rhabdomyosarcoma, among others. The distinctive striking vascular component in AA helps in ruling out most of above-mentioned neoplasms ${ }^{3,10,13,15-19}$.

Commonly, mitoses are not seen but occasional cases may show mild atypia. Immunohistochemical analyses of the tumor, especially the reactivity of desmin, smoothmuscle actin, muscle-specific actin, vimentin, CD 34 , CD44 and negativity for S100 protein, are necessary for the diagnosis. Recurrent tumors usually show similar histological features $7,8,10,11,13,14,20,21$.

It is a slow growing tumor, but local recurrences are frequent (30-72\% of the cases), sometimes even years later. The term "aggressive" was chosen to emphasize the neoplastic nature of the blood vessels, its locally infiltrative nature and the high risk of local recurrence, not to indicate its malignant nature ${ }^{1,10,11,15}$. However, there are two reports of metastasized disease in the literature. Siassi et al. ${ }^{20}$ described a case of a 63 -year-old woman with pulmonary and mediastinal metastatic disease. Blandamura et al. ${ }^{21}$ described the other case in a young woman with multiple local recurrences and metastases in the lungs. 
Owing to its similar clinical presentation to common lesions such as bartholin duct cyst, lipoma, vulvar mass or vulvar abscess, edema caused by chronic venous stasis in the pelvis due to compression, Gartner duct cyst, vaginal cyst, vaginal prolapse or levator hernia, it is often misdiagnosed ${ }^{3}$. So, most cases are diagnosed on histology after primary surgical excision ${ }^{8}$ just like in our case. It has been reported that the misdiagnosis rate of AA varies from 70 to $100 \%{ }^{5}$. Even after sonography, computed tomography (CT) and MRI preoperatively, the diagnosis of AA can be missed ${ }^{22}$.

Sonography shows a mass that is hypoechoic or appears frankly cystic, and adds no additional information. Angiography shows a generally hypervascular mass. On a CT scan, the tumor shows a well-defined margin and iso- or hypo-attenuation compared to the muscles. The swirling appearance is an important diagnostic feature as this is found in about $83 \%$ of the patients $3,4,10,11,23-26$.

MRI, which has a "swirled" pattern visible in the angiomyxoma, is more specific than CT and is thus the imaging study of choice for these lesions. On T1, the tumor shows isosignal compared to the muscles, similar to presentation on $\mathrm{CT}$, and moderate contrast enhancement on a gadolinium scan. On T2-weighted MRI, the tumor has high signal intensity. The attenuation on $\mathrm{CT}$ and high signal intensity on MRI are likely related to the loose myxoid matrix and high water content of angiomyxoma. Both CT and MRI show the translevator and the transdiaphragmatic extent of these tumors $3,4,10,14,26,27$.

In the present case, the patient was not subject of these radiological investigations, as the clinical appearance was suggestive of a vaginal cyst.

Preoperative imaging (CT, MRI) is of crucial importance because the size of the tumor is often underestimated by clinical examination (as in our case), and these diagnostic procedures should make it possible to decide which operative route might be best for the patient. The extent of the tumor can be visualized as well as its involvement into surrounding structures $s^{4,7,10,15}$.

In view of the high risk of local recurrence, wide local excision with tumor-free margins was initially thought to be the treatment of choice. Re-excisions, if the initial surgery was deemed incomplete, were also advocated. Involvement of the bladder, gastrointestinal tract and bone has been described with AA and, in such situations, extensive surgical resection, with significant operative morbidity, would be necessary to achieve clear margins. A review of over 100 cases, however, refuted this belief and showed that patients having positive margins were as likely to have recurrence as those with negative margins $3,4,7,8,28$.

One should aim for complete resection, but incomplete or partial resection is acceptable, especially when high operative morbidity due to extensive surgery is anticipated and preservation of fertility is an issue. Long-term follow-up and careful monitoring with imaging techniques are essential for timely identification of recurrence. However, except for positive surgical margins, there is no clinical or histological predictors for tumor recurrence $3,5,8,10,28,29$.

Most of these tumors show estrogen and progesterone receptor positivity and are likely to be hormone dependent, as rapid growth has been observed during pregnancy. In addition, regrowth during present pregnancy and during subsequent pregnancy have been reported. However, this does not always happen. Hormonal manipulation is thus thought to be a viable treatment option. Several beneficial results with gonadotropin-releasing hormone $(\mathrm{GnRH})$ agonist have been described in primary treatment of small tumors, as adjuvant therapy for residual tumor and even in the treatment of recurrence ${ }^{3,6,8,10,27}$. However, long-term GnRH agonist therapy is associated with side effects such as menopausal symptoms and bone loss ${ }^{10}$. Currently, there are no conclusive data as to the effectiveness of hormonal therapy in the treatment of these tumors ${ }^{4}$. A worry is that the tumor will become resistant to the $\mathrm{GnRH}$ agonist therapy or that withdrawal of the medication may also result in regrowth of the tumor. Pre-operative shrinking of tumors using GnRH analogues might increase chances of complete excision and minimize the radicality of surgical procedure $e^{8,10}$. The optimal duration of therapy is not know ${ }^{10}$.

Owing to its association with hormonal receptors, hormonal methods of contraception may not be suitable, but no evidence either to support or to negate this statement exists in literature. Literature is silent regarding the role of oophorectomy in AA. Since the tumor is receptor positive, oophorectomy may have a potential role in the treatment in women with past middle age and with completed family. However, the role of prophylactic oophorectomy needs to be studied ${ }^{3,10}$.

Due to low mitotic activity, radiotherapy or chemotherapy is unlikely to be a useful adjunct to primary surgery. Most authors did not notice any advantage of radiation therapy ${ }^{2,8,10,30}$. Pre-operative external beam irradiation and intra-operative electron beam radiotherapy was used in one case to reduce risk of recurrence but follow-up data on the same are not available ${ }^{31}$. Two cases of successful control of recurrent angiomyxoma with relatively high doses of external radiotherapy have also been reported ${ }^{32,33}$. We could not find reports on use of chemotherapy in treatment of AA.

Although reported as an alternative approach, embolization or even chemoembolization of AA is not suitable for the majority of these tumors, because most of them are being supplied by more than one feeding vessel ${ }^{10,29,31}$. 
Han-Geurts et al. ${ }^{12}$ propose the following treatment algorithm. If only a minor resection is needed, this would be the treatment of choice. Extensive, mutilating surgery should always be avoided. If arterial embolization and/or hormonal treatment are unsuccessful, resection can be offered, where narrow margins are accepted. Radiotherapy should be reserved for cases without response to embolization or hormonal treatment with persisting complaints and for whom major surgery is warranted to resect the tumor ${ }^{12}$.

So, many options for the treatment of recurrence, such as repeat surgery, radiotherapy and hormonal therapy have been tried with varying success, but no single modality is clearly beneficial over the others. As late recurrences are known, all patients need long-term follow-up, usually with clinical examinations, and MRI is the preferred method for detecting early recurrence. Early detection would be helpful as a smaller tumor would be more amenable to complete and easier surgical excision ${ }^{3,4}$. In conclusion, aggressive angiomyxoma is a rare locally infiltrative tumor, arising mainly in the female pelvis, with a high risk of recurrence. Pre-operative diagnosis is difficult due to rarity and absence of diagnostic features, but it should be considered in every mass in the genital, perianal and pelvic region in a woman in the reproductive age. Knowledge of the condition and complete radiological workup is essential to avoid adverse surgical and prognostic consequences. Surgery is the recommended treatment and it consists of an excision as wide as possible, although the importance of total eradication does not seem to be of crucial significance. The relevance of radiation therapy, embolization and/or hormonal therapy has not been clearly identified yet but may become future alternatives. Long-term follow-up by careful clinical examination is necessary for detection of recurrence, and MRI might be indicated in this setting.

\section{References}

1. Steeper TA, Rosai J. Aggressive angiomyxoma of the female pelvis and perineum. Report of nine cases of a distinctive type of gynecologic soft-tissue neoplasm. Am J Surg Pathol. 1983;7(5):463-75.

2. Magtibay PM, Salmon Z, Keeney GL, Podratz KC. Aggressive angiomyxoma of the female pelvis and perineum: a case series. Int J Gynecol Cancer. 2006; 16(1):396-401 .

3. Dahiya K, Jain S, Duhan N, Nanda S, Kundu P. Aggressive angiomyxoma of vulva and vagina: a series of three cases and review of literature. Arch Gynecol Obstet. 2011 ;283(5): $1145-8$.

4. Foust-Wright $C$, Allen A, Shobeiri SA. Periurethral aggressive angiomyxoma: a case report. Int Urogynecol J. 2013;24(5): 877-80.

5. Wang $Q$, Zhao $M$, Lin X, Zhong W, Gao Y. Aggressive angiomyxoma of the vulva: intra-operative pathological diagnosis is useful in deciding the scope of surgery and reducing recurrence. Acta Chir Belg. 2012;112(1):79-84.

6. Ribaldone R, Piantanida P, Surico D, Boldorini R, Colombo N, Surico N. Aggressive angiomyxoma of the vulva. Gynecol Oncol. 2004;95(3):724-8.

7. Güngör T, Zengeroglu S, Kaleli A, Kuzey GM. Aggressive angiomyxoma of the vulva and vagina. A common problem: misdiagnosis. Eur J Obstet Gynecol Reprod Biol. 2004; 112(1):114-6.

8. Haldar K, Martinek IE, Kehoe S. Aggressive angiomyxoma: a case series and literature review. Eur J Surg Oncol. 2010;36(4):335-9.

9. Nava Flores EL, Álvarez Blanco MA, Figueroa Vadillo J, Cruz Ortiz $\mathrm{H}$. Angiomixoma agresivo de la vulva. Informe de un caso y revisión de la bibliografía. Ginecol Obstet Mex. 2009;77(10):487-90.

10. Dierickx I, Deraedt K, Poppe W, Verguts J. Aggressive angiomyxoma of the vulva: a case report and review of literature. Arch Gynecol Obstet. 2008;277(6):483-7.

11. Smith HO, Worrell RV, Smith AY, Dorin MH, Rosenberg RD, Bartow SA. Aggressive angiomyxoma of the female pelvis and perineum: review of the literature. Gynecol Oncol. 1991;42(1):79-85.
12. Han-Geurts IJ, van Geel AN, van Doorn L, den Bakker M, Eggermont AM, Verhoef C. Aggressive angiomyxoma: multimodality treatments can avoid mutilating surgery. Eu J Surg Oncol. 2006;32(10): 1217-21.

13. Fetsch JF, Laskin WB, Lefkowitz M, Kindblom LG, Meis-Kindblom JM. Aggressive angiomyxoma: a clinicopathologic study of 29 female patients. Cancer. 1996;78(1):79-90.

14. Chen LM, Schink JC, Panares BN, Barbuto D, Lagasse LD. Resection of a giant aggressive angiomyxoma in the Philippines. Gynecol Oncol. 1998;70(3):435-9.

15. Behranwala KA, Thomas JM. Aggressive angiomyxoma: a distinct clinical entity. Eur J Surg Oncol. 2003;29(7):559-63.

16. Cinel L, Taner D, Nabaei SM, Dogan M. Aggressive angiomyxoma of the vagina. Report of a distinctive type gynecologic soft tissue neoplasm. Acta Obstet Gynecol Scand. 2000;79(3):232-3.

17. Jiménez-Vieyra CR, Quintana-Romero V, Aguilera-Maldonado LV, Solís-Moreno TK. Angiomixoma agresivo de vagina: un tumor poco diagnosticado. Ginecol Obstet Mex. 2013;81 (7):403-8.

18. Abdulkader I, Cameselle-Teijeiro J, Forteza G. Angiomixoma agresivo de vulva. Rev Esp Patol. 2003;36(4):441-6.

19. Amith S, Smitha M, Muthuselvam P. Aggressive angiomyxoma of labia majora. A case report and literature review. Gynecol Obstet. 2012;2:126.

20. Siassi RM, Papadopoulos T, Matzel KE. Metastasizing aggressive angiomyxoma. N Engl J Med. 1992;341(23):1772.

21. Blandamura S, Cruz J, Faure Vergara L, Machado Puerto I, Ninfo V. Aggressive angiomyxoma: a second case of metastasis with patient's death. Hum Pathol. 2003;34(10):1072-4.

22. Lin HC, Liu CC, Kang WY, Ke HL, Li CC, Wu WJ, et al. Huge aggressive angiomyxoma: a case report and literature review. Kaohsiung J Med Sci. 2006;22(6):301-4.

23. Amr SS, el-Mallah KO. Aggressive angiomyxoma of the vagina. Int J Gynaecol Obstet. 1995;48(2):207-10. 
24. Yaghoobian J, Zinn D, Ramanathan K, Pinck RL, Hilfer J. Ultrasound and computed tomographic findings in aggressive angiomyxoma of the uterine cervix. J Ultrasound Med. 1987;6(4):209-12.

25. Dragoumis K, Drevelengas A, Chatzigeorgiou K, Assimakopoulos $E$, Venizelos I, Togaridou E, et al. Aggressive angiomyxoma of the vulva extending into the pelvis: report of two cases. J Obstet Gynaecol Res. 2005;31(4):310-3.

26. Outwater EK, Marchetto BE, Wagner BJ, Siegelman ES. Aggressive angiomyxoma: findings on CT and MR imaging. AJR Am J Roentgenol. 1999;172(2):435-8.

27. Gay F, Champigneulle J, Tortuyaux JM, Cuny T, Régent D, LaurentCroisé V. Aggressive angiomyxoma. Diagn Interv Imaging. 2013;94(6):657-61.

28. Chan IM, Hon E, Ngai SW, Ng TY, Wong LC. Aggressive angiomyxoma in females: is radical resection the only option? Acta Obstet Gynecol Scand. 2000;79:216-20.
29. Shahid N, Ahluwalia A, Sahasrabudhe N, Davenport A. Aggressive angiomyxoma of the vagina: a rare differential diagnosis of a lateral vaginal wall cyst. J Obstet Gynaecol. $2005 ; 25(6): 622-3$.

30. Dove S, Remoué P, Valo I, Ybarlucea LR, Panel N, Fondrinier E. Unusual female pelvic tumour: aggressive angiomyxoma. Eur J Obstet Gynecol Reprod Biol. 2008; 137(1):123-5.

31. Nyam DC, Pemberton JH. Large aggressive angiomyxoma of the perineum and pelvis: an alternative approach: report of a case. Dis Colon Rectum. 1998;41(4):514-6.

32. Rhomberg W, Jasarevic Z, Alton R, Kompatscher P, Beer G, Breitfellner $G$. Aggressive angiomyxoma: irradiation for recurrent disease. Strahlenther Onkol. 2000;176(7):324-6.

33. Suleiman $M$, Duc $C$, Ritz S, Bieri S. Pelvic excision of large angiomyxoma in a woman: irradiation for recurrent disease. Int J Gynecol Cancer. 2006; 16(Suppl 1):356-60. 